Informatio: Journal of Library and Information Science Vol. 1(1), 49-66, Januari 2021

ISSN 2775-0043 (Online)

\title{
Pengalaman pemanfaatan cloud storage mahasiswa Teknik Komputer Universitas Diponegoro (Undip) dalam pengelolaan arsip digital
}

\author{
Sinta Wulandari ${ }^{\mathrm{a}^{*}}$, Roro Isyawati Permata Ganggi ${ }^{\mathrm{b}}$ \\ ${ }^{a b}$ Fakultas Ilmu Budaya Universitas Diponegoro Semarang
}

\begin{abstract}
Abstrak
Penggunaan cloud storage setiap mahasiswa tentu berbeda-beda, perilaku yang berbeda-beda juga mempengaruhi bagaimana individu mengelola arsip digital yang dimiliki yang disimpan pada cloud storage serta menggunakannya secara luas. Penelitian ini bertujuan untuk mengetahui bagaimana perilaku pemanfaatan cloud storage yang muncul ketika mengelola arsip digital yang dimiliki mahasiswa dalam kegiatan perkuliahannya. Penelitian ini dilakukan secara kualitatif dengan metode fenomenologi melalui wawancara kepada mahasiswa aktif teknik komputer Undip dan observasi sebagai teknik dalam memperoleh data. Metode analisis data yang digunakan pada penelitian ini adalah metode analisis tematik, yang digunakan untuk menemukan pola atau tema dengan menganalisis data yang didapat kemudian dikaitkan dengan fenomena yang ditemukan melalui kacamata peneliti. Hasil penelitian ini mendapatkan dua tema yaitu pengetahuan mahasiswa terkait pengelolaan arsip digital yang dimiliki menggunakan cloud storage dan perilaku pemanfaatan cloud storage yang dimunculkan oleh mahasiswa teknik komputer. Penelitian ini menunjukkan bahwa Mahasiswa Teknik Komputer Undip sudah terbiasa dengan penggunaan cloud storage sebagai media penyimpanan arsip digitalnya dalam kegiatan perkuliahan. Selama melakukan pengelolaan arsip digital yang dimiliki mahasiswa cenderung dilakukan secara sederhana sesuai dengan pengetahuan dan kemampuan yang dimiliki. Tahap pengelolaan yang dilakukan mulai dari tahap penyeleksian, tahap penataan dan pengelompokkan, tahap evaluasi dan temu kembali. Seluruh tahapan pengelolaan yang dilakukan tentu saling berkaitan satu sama lain. Perilaku pemanfaatan yang ditunjukkan oleh mahasiswa memiliki tujuan yang berbeda-beda dengan berbagai cara untuk membantu kegiatan perkuliahannya. Perilaku pemanfaatan cloud storage yang dilakukan disesuaikan dengan kebutuhan dan kepentingan mahasiswa untuk dapat memenuhi kebutuhan informasi dalam menunjang kegiatan akademiknya.
\end{abstract}

Kata kunci: Cloud Storage; Pengelolaan arsip digital; Perilaku pemanfaatan

Korespondensi: Sinta Wulandari, Fakultas Ilmu Budaya, Jl. Prof. Sudarto No.13, Tembalang, Kec. Tembalang, Kota Semarang, Jawa Tengah 50275, Indonesia

Email: sintawulandari@students.undip.ac.id

http://jurnal.unpad.ac.id/informatio

DOI: https://doi.org/10.24198/inf.v1i1.31111

Received: Desember 2020; Accepted: Januari 2021; Published: Januari 2021

(C) Informatio 2021. This is an open access article under the CC BY-SA license 


\title{
Experience using cloud storage for computer engineering students at Diponegoro University (Undip) in managing digital archives
}

\begin{abstract}
The use of cloud storage every student is certainly different, different behaviors also affect how individuals manage and use the digital archives they have stored in cloud storage. The purpose of this study is to find out how cloud storage behavior emerges when managing digital archives that students have in their educational activities. This study is done qualitatively with phenomenological methods through interviews to active computer engineering students Undip and observation as techniques in obtaining data. The data analysismethod used in this study is thematic analysis method, which is used to find patterns or themes by analyzing the data obtained then associated with the phenomenon found through the researchers' glasses. The results of this study obtained two themes, namely student knowledge regarding the management of digital archives owned using cloud storage and the behavior of using cloud storage that was raised by computer engineering students. While managing digital archives owned by students, it tends to be done simply in accordance with their knowledge and abilities. The management stage is carried out starting from the selection stage, the structuring and grouping stage, the evaluation stage and the meeting again. All stages of management that are carried out are of course related to one another. The utilization behavior shown by students has different goals in various ways to help with their lecture activities. The behavior of using cloud storage that is carried out is adjusted to the needs and interests of students to be able to meet information needs to support their academic activities.
\end{abstract}

Keywords: Cloud storage; Digital archive management; Utilization behavior

\section{PENDAHULUAN}

Arsip digital merupakan arsip yang disimpan menggunakan media elektronik, dapat diakses dengan mudah dan dapat diubah serta memerlukan peralatan khusus untuk dapat melihat, membaca atau mendengarkan. Menurut Read and Ginn (2011), arsip elektronik adalah arsip yang penyimpanannya menggunakan media elektronik sehingga mudah untuk mengakses dan merubahnya. Secara sederhana arsip digital diciptakan untuk memudahkan pengguna dalam mengelola arsip dengan mengikuti perkembangan teknologi yang ada. Meskipun arsip digital rentan terhadap kerusakan dan kehilangan apabila teknologi yang digunakan tidak di update, sehingga arsip digital harus dikelola dengan baik agar dapat digunakan kembali ketika dibutuhkan. Arsip digital dilihat dari dua perspektif yaitu perspektif media penyimpanan dan perspektif proses kegiatan pengelolaan arsip. Perspektif media penyimpanan artinya bahwa arsip memiliki bentuk baru di mana isi dan bentuk fisiknya direkam menggunakan perangkat elektronik, sehingga arsip digital termasuk kelompok dari arsip elektronik (Muhidin et al., 2016).

Salah satu media penyimpanan arsip secara digital yang dapat digunakan adalah media penyimpanan pada cloud storage. Cloud storage merupakan penyimpanan berbasis online dan memerlukan internet untuk dapat mengaksesnya. Ada berbagai jenis cloud storage yang umum digunakan seperti Google Drive, Onedrive, Dropbox dan lain 
sebagainya. Cloud storage menjadi sangat populer saat ini karena mudah digunakan. Keunggulan menggunakan cloud storage yaitu tidak hanya dapat diakses pada komputer saja, namun dapat digunakan pada ponsel android yang dimiliki pengguna, kemudian dapat dilakukan di mana saja baik kantor, di rumah, sekolah bahkan saat berada jauh dari perangkat menggunakan media penyimpanan ini. Selain itu tersedianya fitur sharing memudahkan pengguna untuk berbagi file dengan pengguna lain. Sistem keamanan yang sangat baik juga menjadi salah satu keunggulan yang dimiliki cloud storage karena adanya sistem private cloud (Santiko \& Rosidi, 2018).

Salah satu penelitian yang mengungkapkan adanya penggunaan penyimpanan berbasis awan ini ditulis oleh Srinivasan, Quadir, dan Vijayakumar (2015) dalam penelitiannya menjelaskan dan memperkenalkan komputasi awan seiring dengan evolusi dan manfaat yang ditawarkannya. Penelitian tersebut juga menjelaskan perincian yang terkait dengan komputasi awan dengan menyoroti kemajuan dalam komputasi awan dan efisiensinya di berbagai sektor. Kemudian artikel yang ditulis oleh Ni'matussholiha (2016) Lenawati (2018) juga mengungkapkan bagaimana cloud storage digunakan sebagai media penyimpanan arsip digital yang digunakan di tingkat SMA dan Perguruan tinggi serta menunjukan pola perilaku penggunaan dan pemanfaatan cloud storage dengan membandingkan berbagai jenis cloud storage yang digunakan.

Semakin berkembangnya teknologi dan penggunaan internet di Indonesia memungkinkan masyarakat menggunakan cloud storage sebagai salah satu media penyimpanan arsip digitalnya. Menurut data Asosiasi Penyelenggara Jasa Internet Indonesia (2018) pada tingkat pendidikan perkuliahan terdapat 92,6\% menggunakan internet, dengan demikian mayoritas mahasiswa memanfaatkan internet untuk mendukung kegiatan perkuliahannya. Mahasiswa tentu memiliki banyak kegiatan baik dalam melakukan aktivitas akademik ataupun non akademik yang memerlukan informasi untuk memenuhi kegiatannya. Cloud storage membantu mahasiswa untuk menemukan dan mendapatkan dokumen atau informasi perkuliahan secara cepat, tepat dan mudah dengan demikian adanya penyimpanan digital sangat diperlukan. Burnett and Jaeger berpendapat bahwa era digital pada saat ini menjadikan informasi dengan teknologi memiliki hubungan yang saling berkaitan dalam berbagai aspek kehidupan masyarakat, sehingga menciptakan hubungan yang lebih kuat dengan perilaku informasi di berbagai tingkat masyarakat (Burnett \& Jaeger, 2011).

Universitas Diponegoro (Undip) menjadi salah satu universitas yang sudah mulai berpindah menggunakan sistem digitalisasi, salah satu contoh sistem digitalisasi yang dilakukan yaitu adanya E-Learning. Kuliah online menjadi pilihan untuk melakukan 
perkuliahan apabila mahasiswa dan dosen tidak dapat bertatap muka secara langsung dalam suatu ruangan. Seperti yang terjadi saat ini adanya kasus virus Covid-19 yang menyebar di Indonesia mengharuskan masyarakat melakukan social distancing untuk pencegahan penyebaran virus yang lebih luas. Dengan adanya pembatasan sosial, pemerintah memberikan kebijakan untuk melakukan kegiatan belajar mengajar secara online. Selama perkuliahan online mahasiswa diberikan materi kuliah dan mengumpulkan tugas secara digital. Biasanya mahasiswa memanfaatkan e-mail untuk mengirimkan tugas selama kuliah online. E-mail menjadi salah satu pilihan sebagai media pengiriman file sekaligus sebagai media penyimpanan arsip secara digital.

Selama mengumpulkan tugas mahasiswa Undip sudah tidak lagi menggunakan hard file, akan tetapi dalam bentuk soft file dan mengirimkannya menggunakan e-mail kepada dosen yang bersangkutan. E-mail menjadi salah satu pilihan sebagai media pengiriman file sekaligus menjadi media penyimpanan arsip secara digital. Setiap akun e-mail memiliki fasilitas penyimpanan di cloud storage untuk menyimpan arsip-arsip digital pengguna yang dapat diakses dan digunakan kapanpun ketika arsip tersebut dibutuhkan sehingga media penyimpanan ini dapat digunakan juga oleh mahasiswa untuk menyimpan arsipnya yang berkaitan dengan perkuliahan untuk menunjang kegiatan akademiknya. Hal tersebut membuktikan bahwa mahasiswa Undip juga sadar dan mendukung adanya digitalisasi yang mempermudah dalam kegiatan perkuliahan guna mewujudkan misi untuk menjadikan Undip sebagai World class University.

Penelitian yang dilakukan oleh Widjaja (2019) mengungkapkan bahwa kesediaan pengguna untuk menyimpan informasi pribadinya pada cloud sangat dipengaruhi oleh kepercayaan, biaya, manfaat dan tingkat kepekaan informasi pribadinya. Meskipun ada ancaman dalam penyimpanan dan keamanan, pengguna tetap menggunakan cloud untuk menyimpan informasi pribadinya, sehingga setiap pengguna memiliki berbagai pertimbangan yang berbeda untuk menyimpan arsipnya pada cloud storage. Persamaan penelitian ini dengan penelitian yang dilakukan penulis yaitu berkaitan dengan arsip digital pribadi, bagaimana pengguna cloud storage dalam menyimpan arsip digitalnya dan kepercayaan pengguna untuk menyimpan arsip digitalnya pada penyimpanan berbasis cloud.

Banyaknya arsip yang dimiliki mahasiswa Prodi Teknik Komputer Undip memerlukan adanya pengelolaan yang tepat supaya mempermudah kegiatan yang dilakukan selama perkuliahan dan juga dapat menemukan secara cepat arsip yang disimpan ketika dibutuhkan. Oh (2019) memunculkan model pengorganisasian arsip pribadi yang dibutuhkan sehari-hari untuk membantu pengguna dalam menangani arsip digital pribadi 
yang dimiliki dengan menggunakan model yang ditemukannya. Ia juga mengidentifikasi tahapan proses serta tindakan, pemikiran, keputusan dan faktor-faktor yang terlibat dalam proses konteks kehidupan sehari-hari. Penelitian tersebut dijadikan acuan peneliti untuk menganalisis proses pengelolaan yang dilakukan Mahasiswa Teknik Komputer Undip.

Ada enam tahap dalam pengorganisasian informasi pribadi secara digital, dalam setiap tahapan terdapat aspek penting yang mempengaruhi. Adapun tahap tersebut yaitu:

\section{Initiation}

Pada tahap inisiasi hal pertama yang dilakukan yaitu action dimulai dengan membuat file, menyalin file yang sudah ada, dan penerimaan file dengan cara lain seperti mengunduh file melalui e-mail atau situs web. Kemudian pemilik file merasakan kekacauan dalam mengorganisir informasi yang dimiliki sehingga mulai berpikir bagaimana caranya untuk menata dan merapikan file-file yang dimilikinya.

Pada tahap initiation ini pengguna mulai membuat keputusan untuk mengorganisir informasi pribadinya dengan melihat beberapa faktor yang mempengaruhi. Adapun faktor yang mempengaruhi yaitu penggunaan yang berarti apakah file tersebut sedang digunakan atau tidak, serta apakah itu akan digunakan di masa depan atau tidak. Kemudian nilai yaitu mengacu pada arti sebuah file yang dimiliki seseorang, seperti file yang menarik, lucu ataupun penting. Selain itu, Aksesibilitas juga mempengaruhi keputusan seseorang untuk menyimpan file karena untuk memudahkan aksesnya. Faktor selanjutnya yaitu sistem yang berarti sistem otomatis atau pengaturan default perangkat lunak tertentu, web browser atau perangkat pribadi karena terkadang secara otomatis menyimpan atau mengunggah file ke perangkat pribadi.

\section{Identification}

Setelah memutuskan untuk menyimpan file, kemudian tahap selanjutnya adalah mengidentifikasi file untuk mencari tahu cara mengaturnya seperti memberi nama pada file tersebut sesuai dengan kebutuhannya. Faktor utama yang mempengaruhi tahap identifikasi yaitu tujuan dibuatnya file tersebut. Selain itu ada beberapa faktor yang mempengaruhi yaitu jenis file (tipe umum atau genre file), format file ( $p d f$, docx, jpg), topik file (tentang file seperti liburan, kuliah, SMA), waktu dimensi file (mis. tahun, musim, semester, minggu, atau hari), Orang terkait (yaitu orang yang terkait dengan mengajukan), dan sumber file (tempat memperoleh file seperti jurnal, website). Faktor-faktor lain yang mempengaruhi tahap ini yaitu penggunaan file (misalnya "itu hanya untuk sekali penggunaan istilah"), dan nilai file (misalnya "ini adalah salah satu acara TV favorit"). 


\section{Temporary Categorization}

Tahap ini biasanya file disimpan dalam desktop atau cloud computing yang diaksesnya daripada disimpan secara permanen dan ditata sesuai dengan kebutuhan. Hal ini dianggap sebagai kategori sementara. Pada tahap ini seseorang individu menunda untuk melakukan pengorganisasian informasi pribadinya. Faktor yang memiliki pengaruh terbesar pada tahap ini adalah faktor penggunaan file. Seringnya file disimpan di lokasi sementara ketika ada kegunaan yang sedang berlangsung untuk file tersebut. Selain itu juga mempengaruhi keputusan untuk melakukan kategorisasi ulang file (mis. penggunaan di masa mendatang), menghapus file (mis. tidak ada penggunaan di masa depan) dan menyimpan file. Kemudian faktor aksesibilitas file seperti keputusan untuk menyimpan file ke lokasi sementara ketika mereka membutuhkan akses cepat, mudah atau sering digunakan. Selanjutnya faktor ketersediaan waktu yaitu mengacu pada lamanya waktu yang tersedia ketika mengatur file. File disimpan di lokasi sementara ketika tidak memiliki cukup waktu untuk membuat keputusan menata secara permanen.

\section{Examination/Comparison}

Pada tahap ini file diperiksa untuk melihat apakah folder yang dimiliki relevan dan dapat ditata secara permanen. Hal yang dilakukan dalam proses ini adalah meninjau isi dan folder-folder yang ada. Saat meninjau folder yang ada juga menilai kesamaan dan perbedaan antara file baru dan yang ada di folder yang relevan untuk menemukan tempat yang tepat untuk file baru. Faktor yang sangat mempengaruhi ketika meninjau folder adalah tujuan dari file tersebut. Hal ini terjadi karena untuk mengingat dan menyimpan file secara permanen. Kemudian faktor lain yang mempengaruhi adalah waktu seperti semester atau tahun relevan dengan file, orang terkait misalnya lulusan siswa atau anggota keluarga, format, topik, jenis, afiliasi (mis. nama universitas), aksesibilitas dan penggunaan file.

\section{Selection/Creation/Modification}

Pada tahap ini, jika ditemukan folder yang relevan untuk mengatur file maka folder tersebut dipilih untuk menyimpan informasi yang dimiliki. Kemudian disesuaikan antara file yang baru dan file yang ada di folder tersebut untuk memutuskan apakah akan disimpan, memodifikasi atau membuat folder yang lebih rinci lagi. Ketika memilih salah satu folder yang ada kemudian menyesuaikan dengan meningkatkan kesamaan dan mengurangi perbedaan antara file baru dan file yang ada di folder yang permanen. Tahap ini memiliki berbagai faktor yang mempengaruhi proses. Faktor yang memiliki dampak terbesar adalah tujuan dari file tersebut. Seringnya hal yang dilakukan yaitu memilih folder ketika file memiliki tujuan yang sama, atau membuat kategori baru ketika file itu untuk 
tujuan baru. Faktor lain yang mempengaruhi adalah aksesibilitas, waktu, topik, penggunaan, jumlah file, dan lain sebagainya.

\section{Categorization}

Pada tahap ini individu menempatkan file ke dalam folder. Ketika file disusun dalam folder, mereka merasa bahwa file yang dimiliki sudah terorganisir dengan baik. Sementara itu kategorisasi mungkin tampak seperti tahap akhir dari proses pengorganisasian dengan beberapa keputusan yang dibuat dalam hal tahap ini. Faktor penggunaan file memiliki dampak terbesar pada tahap ini, dan itu mepengaruhi keputusan mereka dengan berbagai cara seperti mengkategorikan ketika file sedang digunakan, kemudian mengkategorikan ulang file saat tidak ada penggunaan yang sedang berlangsung. Faktor lain yang mempengaruhi tahap ini adalah aksesibilitas agar mudah dalam menemukan informasi yang dibutuhkan, kesesuaian penyimpanan, jumlah file, tujuan, ketersediaan waktu dan nilai. Setiap mahasiswa tentu memiliki penyimpanan cadangan berbasis digital untuk back up data mereka. Dalam penggunaannya pun berbeda-beda. Perilaku yang berbeda-beda juga mempengaruhi bagaimana individu mengelola arsip digital yang dimiliki yang disimpan pada cloud storage serta menggunakannya secara luas.

Penggunaan yang berbeda disesuaikan dengan kebutuhan dan pengetahuan mahasiswa dalam mengelola informasi yang dimiliki. Dalam dunia teknologi informasi pemanfaatan cloud storage sebagai media penyimpanan arsip digital menjadi hal yang sudah biasa dilakukan. Pemanfaatan yang dilakukan bertujuan untuk membantu meringankan pekerjaan dan menjaga arsip digital yang dimiliki tetap aman dan mudah untuk diakses. Adanya perkembangan teknologi informasi memberikan dampak terhadap perilaku penggunaan yang dimunculkan. Perilaku pemanfaatan cloud storage yang muncul tentu berbeda-beda yang disesuaikan dengan kebutuhan dan kepentingan penggunanya.

Ananda Dwi (2013) mengungkapkan perkembangan teknologi informasi memiliki pengaruh besar dalam dunia pendidikan khususnya pada proses belajar mengajar, dengan berkembangnya penggunaan teknologi informasi ada 5 (lima) pergeseran dalam proses pembelajaran yaitu dari pelatihan ke penampilan, dari ruang kelas ke dimana dan kapan saja, dari kertas ke online atau saluran, fasilitas fisik ke fasilitas jaringan kerja dan dari waktu siklus ke waktu nyata. Pemanfaatan teknologi informasi digunakan untuk membantu pengajar menyampaikan materi dan informasi yang berkaitan dengan pelaksanaan belajar mengajar. Memanfaatkan teknologi informasi dalam proses pembelajaran merupakan bentuk adaptasi pengembangan ilmu pengetahuan yang berkembang saat ini. Komunikasi dalam proses belajar mengajar yang dilakukan antara 
pengajar dan siswanya menggunakan media-media komunikasi seperti telepon, $e$-mail, dan juga internet.

Menurut Mildawati (2016) adanya perkembangan teknologi informasi juga memberikan dampak terhadap perilaku penggunaan yang dimunculkan, misalnya berbagai fenomena media sosial dan pengaturan informasi secara digital seperti membuat, menyusun, membagi, dan mengatur informasi dilakukan di lingkungan online. Pada lingkup ilmu sosial meskipun tidak jarang dimana perilaku manusia sulit dan kompleks untuk dijelaskan, tetapi juga mempersulit upaya praktisi Teknologi Informasi (TI) dan akademisi untuk mengidentifikasi perilaku penerimaan pengguna. Dengan demikian, penelitian ini menjadi penting untuk dilakukan agar dapat mengkaji lebih dalam bagaimana pengalaman mahasiswa yang dimunculkan selama memanfaatkan cloud storage dalam mengelola arsip digitalnya.

\section{METODE PENELITIAN}

Perilaku seseorang merupakan data non-statistik atau tidak menggunakan angka yang disajikan menggunakan data yang di deskripsikan secara detail setelah melakukan pengamatan. Menurut Lexy (2013) Penelitian kualitatif menjadi penelitian dengan hasil deskriptif dengan serangkaian kata untuk memahami fenomena yang diteliti. Dengan demikian, metode kualitatif tepat digunakan untuk mengeksplorasi bagaimana perilaku pemanfaatan cloud storage dalam pengelolaan arsip digital mahasiswa. Penelitian ini menggunakan pendekatan fenomenologi. Pendekatan fenomenologi menggambarkan sebuah pengalaman individu yang dialami dan memahami makna pengalaman itu bagi dirinya. Pengalaman yang dimaksud yaitu sebuah tindakan yang dilakukan dalam kehidupannya. Pada fenomenologi pengalaman hidup merupakan suatu data dasar dari sebuah realita sehingga penting untuk mengembangkan metode tanpa memalsukan fenomena dan mendeskripsikan seperti apa yang terlihat. Pendekatan fenomenologi berusaha untuk memahami lebih jauh makna dari suatu peristiwa yang saling berpengaruh dengan manusia (Iskandar, 2013).

Peneliti memiliki kriteria untuk mendapatkan partisipan, teknik ini disebut dengan teknik purposive sampling, yaitu salah satu strategi pengambilan sampel yang digunakan dalam memilih partisipan sesuai dengan kriteria yang dipilih agar relevan dan sesuai dengan pertanyaan penelitian (Wahyuni, 2012). Adapun kriteria yang ditentukan agar sesuai dengan tujuan penelitian adalah mahasiswa aktif Prodi Teknik Komputer Universitas Diponegoro yang menggunakan cloud storage sebagai media penyimpanan arsip digitalnya. 
Peneliti mengaplikasikan wawancara semi terstruktur, observasi dan studi dokumentasi sebagai teknik pengambilan data.

Wawancara digunakan untuk mendapatkan informasi yang lengkap, mendalam, dan menyeluruh. Pendekatan yang dilakukan dalam wawancara adalah pendekatan non formal. Kemudian penelitian ini menggunakan observasi partisipan pasif yaitu peneliti mendatangi informan untuk melihat bagaimana informan melakukan kegiatannya akan tetapi peneliti tidak ikut terlibat dalam kegiatan tersebut. Peneliti mengamati setiap perilaku dan situasi yang ada di lingkup penelitian untuk menghasilkan suatu jawaban. Selanjutnya penelitian ini menggunakan metode studi dokumentasi dengan cara mengambil gambar cloud storage yang digunakan untuk melihat bagaimana pengelolaan arsip digital yang disimpan mahasiswa teknik komputer Universitas Diponegoro (Undip) pada cloud storage tersebut, dengan demikian peneliti dapat mencocokkan antara hasil wawancara dengan dokumentasi yang diberikan untuk menguatkan data yang diperoleh.

Data yang terkumpul kemudian dianalisis menggunakan metode analisis tematik. Analisis tematik digunakan untuk menemukan pola atau tema dengan menganalisis data yang sudah didapat yang dikaitkan dengan fenomena-fenomena yang ditemukan melalui kacamata peneliti (Heriyanto, 2018). Peneliti memahami bahwa identifikasi pola penelitian dapat membantu menganalisis fokus penelitian ini, yaitu perilaku pemanfaatan cloud storage mahasiswa dalam pengelolaan arsip digitalnya. Analisis tematik memiliki beberapa tahap untuk menganalisis data yaitu tahap memahami data, coding, dan tahap penentuan tema. Semua tahap tersebut saling berkaitan untuk menemukan pola (pattern) dari fenomena yang sedang dikaji.

\section{HASIL DAN PEMBAHASAN}

Berdasarkan hasil wawancara yang peneliti lakukan mengungkapkan bahwa mahasiswa teknik komputer menggunakan beberapa jenis cloud storage, namun mereka hanya memaksimalkan penggunaannya pada satu jenis cloud storage untuk melakukan penyimpanan yang dimiliki. Cloud storage yang sering digunakan oleh kalangan mahasiswa ini antara lain google drive, onedrive, dan juga dropbox, sedangkan cloud storage yang mereka maksimalkan penggunaannya adalah google drive, dengan membuat akun gmail secara otomatis mereka memiliki fasilitas penyimpanan cloud yang disediakan google dari akun gmail yang dibuat. Cara penggunaan yang mudah dipahami mendorong mahasiswa untuk memanfaatkan cloud storage yang disediakan. Mereka mengetahui cara menggunakan dan memanfaatkan cloud storage berasal dari diri sendiri, guru, teman sekolah dan juga saudara. 
Cloud storage menjadi salah satu pilihan sebagai media penyimpanan data yang dimiliki. Data yang disimpan pada cloud storage oleh mahasiswa teknik komputer antara lain terkait dengan kegiatan perkuliahan, organisasi, data penting pribadi dan juga pekerjaan. Salah satu informan mengungkapkan bahwa dia memanfaatkan dua jenis cloud storage untuk fungsi yang berbeda:

"Kalau perkuliahan pakai Onedrive karena kebanyakan pakai Microsoft word, pdf gitu. Pokoknya file-file yang berhubungan dengan Microsoft ya save nya langsung Onedrive. saya pakai Onedrive baru-baru ini, jadi saya punya laptop dan segala dokumen seperti word yang menggunakan microsoft disediakan cloudnya pakai Onedrive jadi saya bisa akses lewat laptop atau PC di rumah. Kalau google drive kebetulan saya sudah kerja jadi file-file kerja, saya simpan di google drive semua”(A. Tama, personal communication, June 26, 2020)

Setiap orang memiliki pilihan yang berbeda-beda, sama halnya dengan memilih data untuk disimpan pada cloud storage. Setiap mahasiswa memiliki kepentingan tersendiri saat memilih cloud storage sebagai media penyimpanan data dan pengelolaan arsip digitalnya. Pengelolaan yang dilakukan oleh mahasiswa teknik komputer terhadap arsip digital yang dimiliki cukup sederhana dan disesuaikan dengan kepentingan pada arsip yang disimpan. Adapun pengelolaan yang dilakukan yaitu penyeleksian file, penataan dan pengelompokkan, evaluasi dan temu kembali.

1. Tahap penyeleksian

Tahap penyeleksian merupakan tahap awal dimana mahasiswa memilih dan memilah file yang akan disimpan pada cloud storage yang digunakan. Sebelum mengunggah file dan menyimpan pada cloud, file diseleksi terlebih dahulu dengan berbagai pertimbangan. Pertimbangan yang dilakukan yaitu tingkat kepentingan file tersebut untuk disimpan pada cloud storage, berapa lama jangka waktu yang dibutuhkan untuk menyimpan file tersebut, ukuran file, tingkat kebutuhan, dan tujuan menyimpan file. Penyeleksian ini dilakukan oleh mahasiswa teknik komputer untuk memilih berbagai file penting dan menghindari penumpukan file yang akan disimpan serta menyesuaikan dengan penggunaan file tersebut. Penyeleksian bertujuan untuk memudahkan akses file agar dapat digunakan dimana saja dan kapan saja saat dibutuhkan.

Tahap penyeleksian ini juga dipengaruhi beberapa faktor, Hal yang menjadi faktor utama dalam melakukan penyeleksian yaitu penggunaan. Faktor penggunaan yang dimaksud yaitu file yang diseleksi untuk disimpan merupakan file yang akan digunakan saat itu atau untuk waktu yang lama misalnya untuk kepentingan print 
out atau tugas. Kemudian faktor selanjutnya yaitu nilai, dalam hal ini file yang diseleksi merupakan file penting atau menarik misalnya materi kuliah atau mock up desain. Faktor selanjutnya yaitu aksesibilitas, file yang disimpan memudahkan untuk diakses dimanapun dan kapanpun mereka membutuhkannya seperti saat mereka hendak melaksanakan ujian dan membutuhkan materi ujian untuk dipelajari kapanpun di tempat yang nyaman.

2. Tahap penataan dan pengelompokkan

Tahap selanjutnya yaitu penataan dan pengelompokkan. Setelah file di unggah dengan melalui proses seleksi terlebih dahulu, file tersebut di tata dan dikelompokkan sesuai dengan kepentingannya. Penataan ini bertujuan untuk merapikan arsip yang tersimpan pada cloud storage, sedangkan pengelompokkan bertujuan untuk memudahkan pengguna saat menggunakannya agar tidak tercampur dengan file lain yang tidak saling berkaitan. Pengelompokkan yang dilakukan ada yang berdasarkan kategori dan kepentingannya. Kegiatan pengelompokkan disesuaikan dengan kebutuhan penggunanya, sehingga tiap pengguna memiliki cara sendiri untuk mengelompokkan arsip yang dimiliki. Hal ini tentu memiliki latar belakang dan alasan tersendiri bagi setiap pengguna. Salah satu alasan mengelompokkan dan menata arsip digitalnya seperti hal di atas yaitu untuk memudahkan saat melakukan pencarian ketika akan menggunakannya.

Tahap penataan dan pengelompokkan dipengaruhi oleh satu faktor yang sama yaitu penggunaan yang memiliki pengaruh besar untuk memutuskan sebuah file saat di kategorikan dan dikelompokkan. Kemudian selain faktor penggunaan ada beberapa faktor lain yang mempengaruhinya, Faktor pertama yaitu tujuan, tujuan yang dimaksud adalah file yang disimpan memiliki tujuan tertentu sesuai dengan kebutuhan penggunanya. Kemudian menjadi pengingat adanya file yang harus disimpan dalam jangka waktu yang lama bahkan untuk disimpan secara permanen. Faktor selanjutnya yaitu aksesibilitas, file disimpan untuk dapat digunakan pada waktu yang tidak dapat diprediksi oleh pengguna. File yang disimpan juga dapat diakses dimana saja saat dibutuhkan dengan perangkat yang mudah digunakan. Kemudian faktor yang lain yaitu adanya pengelompokkan yang dapat dilakukan berdasarkan jenis (video, foto, dokumen, gambar), format (docx, $p d f$, jpg, dll), topik (liburan, organisasi, kuliah, dll), dan juga waktu (semester, tahun, bulan). Pada proses penataan dan pengelompokkan file tidak sedikit mahasiswa yang masih mengabaikan kegiatan ini dengan alasan malas dan memiliki 
tingkat kepedulian yang rendah dengan arsip yang disimpannya. Sehingga arsip yang telah diunggah tersimpan begitu saja tanpa ditata dan dikelompokkan.

3. Tahap evaluasi

Tahap selanjutnya adalah evaluasi, evaluasi disini dilakukan check and recheck file yang masih dipakai atau file yang tidak dibutuhkan lagi. Evaluasi juga dilakukan untuk mengetahui apakah kapasitas penyimpanan yang disediakan cloud storage masih cukup untuk menampung file lebih banyak lagi. Tahap ini dilakukan tidak setiap saat oleh pengguna, ada yang melakukan setahun sekali, setiap bulan atau setiap akhir semester. Semua berdasarkan dengan kecukupan waktu dan kapasitasnya, kecuali saat melihat kapasitas penyimpanan yang sudah menipis dan membutuhkan banyak ruang untuk file baru yang akan disimpan maka saat itulah evaluasi dilakukan. Namun evaluasi yang dilakukan juga tidak menyeluruh hanya dilakukan sekilas dengan menghapus beberapa file yang sudah tidak dibutuhkan atau dipakai lagi tanpa adanya pertimbangan penggunaan di masa yang akan datang.

Tahap evaluasi juga dilakukan dengan faktor yang mempengaruhi yaitu tujuan dari adanya arsip dan folder yang dibuat atau dimiliki. Kemudian faktor lain yang juga mempengaruhi tahap evaluasi adalah aksesibilitas, waktu, topik, dan juga penggunaan. Semua faktor tersebut juga menjadi pertimbangan saat melakukan evaluasi untuk memastikan setiap arsip yang dimiliki sudah tersimpan dengan tepat dan sesuai dengan kebutuhannya serta sebagai pertimbangan untuk mengambil keputusan terhadap arsip yang dimiliki.

4. Temu kembali

Tahap terakhir pada pengelolaan arsip yang dilakukan mahasiswa teknik komputer adalah tahap temu kembali. Pengelolaan arsip pada dasarnya dilakukan untuk memudahkan temu kembali arsip saat dibutuhkan. Sama halnya dengan melakukan pengelolaan pada arsip digital. Arsip disusun, ditata dan dikelompokkan untuk memudahkan temu kembali saat membutuhkannya. Pada kasus ini mahasiswa teknik komputer yang melakukan penataan dan pengelompokkan cenderung melakukan temu kembali dengan mudah dan langsung tertuju kepada arsip yang dibutuhkan. Mahasiswa yang tidak melakukan penataan dan pengelompokkan memilih cara menggunakan menu search untuk mencari file yang dibutuhkan dengan keyword yang sesuai. Keyword yang digunakan biasanya berdasarkan dengan nama file yang disimpan atau menggunakan keyword sesuai dengan apa yang diingat. 
Selama menggunakan menu search mahasiswa cukup kesulitan apabila keyword yang digunakan tidak sesuai dan lupa dengan nama file yang sudah tersimpan sehingga harus melakukan scroll up untuk mendapatkan file yang dibutuhkan. Berbeda dengan mahasiswa yang sudah terbiasa dengan hal tersebut yang memilih cara mengurutkan tanggal, bulan atau tahun saat melakukan pengunggahan file, dengan demikian mempermudah mendapatkan file yang dibutuhkan dengan cepat meskipun tidak dikelompokkan. Pemanfaatan cloud storage memiliki tujuan yang berbeda-beda dari setiap penggunanya mulai dari media penyimpanan atau sekedar memanfaatkan fitur yang ada untuk menyelesaikan pekerjaan. Sama halnya dengan yang dilakukan oleh Mahasiswa Teknik Komputer Undip dalam memanfaatkan cloud storage dengan berbagai macam cara dalam kegiatan perkuliahannya.

Mahasiswa Teknik Komputer Undip memanfaatkan cloud storage sebagai penyimpanan database dan media back up data yang dimiliki. Hal ini dilakukan karena cloud storage memiliki tingkat keamanan dan kenyamanan yang cukup tinggi dalam menggunakannya. Seperti yang diungkapkan oleh salah satu informan yaitu sebagai berikut:

"Awalnya aku mau back up data karena aku sering instal ulang laptop, karena takut hilang kalau cuma nyimpen di harddisk akhirnya yaa itu di cloud kan datanya lebih aman. Kalau di penyimpanan konvensional kan kita gatau kalau tiba-tiba nanti komputer kita mati atau rusak apalagi ancaman virus. balik lagi kaya alasan aku pakai cloud jadi datanya aman, dan data lama yang disimpan juga masih bisa diakses kapanpun, kenyamanan penggunanya karena bisa diakses dimana aja." (R, Aziz, personal communication, June 27, 2020)

Kemudian penggunaan yang fleksibel juga menjadi faktor mahasiswa untuk memanfaatkannya. Fleksibel yang dimaksudkan yaitu cloud storage dapat digunakan dimana saja dan kapan saja saat mahasiswa membutuhkannya tanpa harus membawa media penyimpanan eksternal seperti flashdisk atau harddisk. Contoh sederhana ketika mahasiswa hendak mencetak tugas yang akan dikumpulkan, mereka tidak perlu repot membawa alat penyimpanan eksternal untuk membuka file yang dibutuhkan. Mereka cukup mengunggah file tersebut pada cloud agar dapat diakses menggunakan komputer yang disediakan tempat percetakan.

"Faktor utama nya sih buat ngeprint ya terutama tugas, karena kalau menggunakan flashdisk itu suka error di beberapa tempat print. Kalau buat materi tugas karena lebih fleksibel aja bisa dibaca melalui hp/tab, jadi gaperlu 
membawa laptop terus kemana-mana." (A, personal communication, June 26, 2020)

Contoh lain seperti saat mahasiswa akan mempelajari materi ujian atau membaca file penting, mereka tidak perlu membawa tumpukan kertas print out atau membawa laptop untuk dijadikan sebagai media agar dapat membaca materi tersebut. Akan tetapi mereka dapat mengakses materi dengan sebuah smartphone saja untuk dapat membaca file, hal ini tentu sangat memudahkan pengguna selain fleksibel juga sangat efisien.

"Faktornya yaa bergantung sama kepentingan, misalnya file kuliah yang aku simpen dan aku gunain buat uas, karena aksesnya bisa lewat hp jadi bisa aku baca sambil nongkrong atau lagi ngga di kos gitu, terus file organisasi kaya list kegiatan atau rencana yang bisa aku buka kapan aja buat pengingat atau mempelajarinya."(K, personal communication, June 26, 2020)

Cloud storage tidak hanya menjadi media penyimpanan arsip digital saja akan tetapi dengan layanan yang dimiliki dapat digunakan untuk membantu kegiatan perkuliahan mahasiswa. Pada kegiatan perkuliahan dosen dan mahasiswa sering memanfaatkan fitur berbagi file dengan link untuk saling berbagi materi dan mengumpulkan tugas. Fitur ini memudahkan dosen dan mahasiswa untuk berinteraksi dalam kegiatan belajar mengajar. Terlebih saat seperti ini dimana seluruh kegiatan belajar mengajar dilakukan secara online. Kemudian layanan berbagi file juga dimanfaatkan Mahasiswa Teknik Komputer Undip ketika mereka sedang menjalani project bersama. Pada kegiatan berbagi file ini mahasiswa tidak memerlukan pembaruan secara manual dan saling menyalin hasil pekerjaan yang sedang dikerjakan tetapi file yang dimiliki bersama akan melakukan pembaruan secara otomatis saat digunakan dan disimpan. Fitur penunjang lainnya seperti Word, PDF, Form dan lainnya juga menjadi salah satu hal yang dimanfaatkan oleh pengguna untuk mendukung kegiatan perkuliahan. Fitur ini dapat digunakan tanpa harus mengunduh aplikasi serupa. Selain itu, fitur seperti ini juga dapat digunakan secara bersamaan tanpa adanya batasan waktu.

Perilaku penggunaan cloud storage yang dimunculkan oleh Mahasiswa Teknik Komputer Undip memiliki kesesuaian dengan perilaku penerimaan teknologi informasi pada model Technology Acceptance Model (TAM)(Alharbi \& Drew, 2014). Menurut Alharbi \& Drew (2014) dari aliran penelitian tentang sistem informasi, banyak teori yang telah diajukan untuk menjelaskan hubungan antara faktor penentu yang akan mempengaruhi penerimaan teknologi. Faktor yang paling umum adalah sikap, persepsi, keyakinan, dan penggunaan sistem pengguna yang sebenarnya. TAM pertama kali diperkenalkan oleh Davis pada tahun 1989 terkait konsep penerimaan teknologi, TAM berpendapat bahwa penerimaan teknologi baru dapat diprediksi berdasarkan niat perilaku 
pengguna, sikap terhadap penggunaan, dan keyakinan internal lainnya yaitu kegunaan yang dirasakan dan persepsi kemudahan penggunaan. Kegunaan yang dirasakan sebagai "probabilitas subyektif calon pengguna bahwa menggunakan sebuah sistem atau teknologi tertentu akan meningkatkan kinerja pekerjaannya dan kemudahan penggunaan yang dirasakan sebagai "sejauh mana calon pengguna mengharapkan sistem target bebas dari usaha".

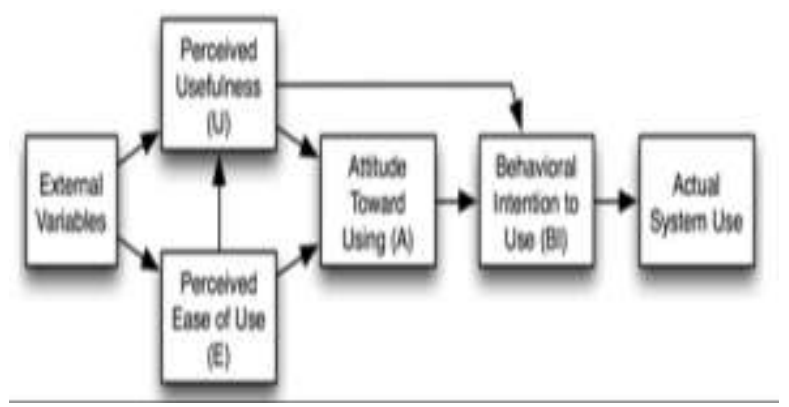

Gambar 1. The Original Technology Acceptance Model (TAM) Sumber: Alharbi (2014)

Mahasiswa Teknik Komputer Undip tentu mengalami banyak pengalaman yang dilalui selama menggunakan cloud storage. Pengalaman yang dimiliki menentukan pekerjaan/tugas yang dikerjakan. Adanya pengalaman penggunaan yang dilakukan Mahasiswa Teknik Komputer Undip secara tidak langsung mereka merasakan manfaat dalam menggunakan cloud storage. Manfaat penggunaan inilah yang menjadikan mahasiswa untuk terus-menerus menggunakan cloud storage sebagai media penyimpanan arsip digitalnya dan melakukan penyelesaian tugas yang diberikan oleh setiap dosen. Mahasiswa Teknik Komputer Undip memiliki fleksibilitas akses yang sangat luas pada cloud storage. Mereka dapat mengakses arsip yang dimiliki yang tersimpan pada cloud storage kapanpun dan dimanapun mereka membutuhkannya. Penggunaan cloud storage juga memberikan kemudahan mahasiswa untuk cepat memahami cara menguasai sistem dan penggunaan fitur yang disediakan oleh cloud storage itu sendiri.

Perilaku yang ditunjukkan mahasiswa saat dihadapkan dengan sebuah teknologi sangat mempengaruhi sikap penerimaan dan penolakan pada teknologi tersebut. Perilaku penggunaan dan kemudahan dalam menggunakan serta menguasai sistem pada cloud storage yang ditunjukkan oleh Mahasiswa Teknik Komputer Undip mengartikan bahwa mahasiswa menerima adanya cloud storage. Sikap penerimaan yang ada mendorong Mahasiswa Teknik Komputer Undip untuk tetap menggunakan dan mengakses cloud 
storage sebagai media penyimpanan arsip digital dan sarana pembelajaran dalam kegiatan perkuliahan. Kegiatan yang dilakukan dalam menggunakan dan mengakses cloud storage secara terus menerus dengan frekuensi yang cukup tinggi menunjukkan bahwa tindakan tersebut menjadi sistem secara aktual.

Seluruh perilaku pemanfaatan cloud storage yang dilakukan Mahasiswa Teknik Komputer Undip sangat beragam dan berbeda-beda, hal ini terbentuk dengan adanya dorongan kebutuhan dan kepentingan setiap orang untuk memanfaatkannya. Adanya cloud storage tentu sangat berpengaruh pada kegiatan perkuliahan mereka. Minimnya pengetahuan dan tingkat kepedulian yang rendah terhadap pengelolaan arsip digital yang dimiliki menjadikan mahasiswa kurang dapat memaksimalkan layanan yang diberikan oleh masing-masing cloud storage yang digunakan.

\section{SIMPULAN}

Pengelolaan yang dilakukan Mahasiswa Teknik Komputer Undip terhadap arsip digital yang disimpan pada cloud storage cukup sederhana yang disesuaikan dengan kepentingan arsipnya. Tahap pengelolaan yang dilakukan mulai dari tahap penyeleksian, tahap penataan dan pengelompokkan, tahap evaluasi dan temu kembali. Seluruh tahapan pengelolaan yang dilakukan tentu saling berkaitan satu sama lain dengan tujuan agar dapat mudah ditemukan saat dibutuhkan dan akan digunakan oleh mahasiswa. Pemanfaatan cloud storage oleh Mahasiswa Teknik Komputer Undip menunjukkan berbagai perilaku pemanfaatan yang memiliki tujuan berbeda-beda dengan berbagai cara. Perilaku pemanfaatan cloud storage oleh mahasiswa meliputi perilaku pemanfaatan sebagai media penyimpanan data, media back up data, penyimpanan database, dan pemanfaatan fitur serta layanan yang disediakan cloud storage dalam kegiatan perkuliahannya. Perilaku pemanfaatan yang dimunculkan sesuai dengan perilaku pemanfaatan teknologi informasi yang diperoleh Mahasiswa Teknik Komputer Undip dari pengalamannya selama menggunakan cloud storage.

Hasil penelitian yang ditemukan dapat menjadi pembelajaran pada penelitian sejenis dengan lingkup yang sama. Kemudian penelitian ini dapat dikembangkan dengan fokus yang berbeda, untuk itu sangat dimungkinkan untuk melakukan penelitian dengan subjek maupun objek di luar program studi tersebut dan di luar bidang pendidikan, karena kemungkinan akan dijumpai fenomena yang berbeda dengan adanya perbedaan kultur pada tiap-tiap lingkungan yang terbentuk. Semua tahap tersebut saling berkaitan untuk menemukan pola (pattern) dari fenomena yang sedang dikaji.

Pengalaman pemanfaatan cloud storage mahasiswa teknik komputer Universitas Diponegoro (Undip) dalam pengelolaan arsip digital

(Sinta Wulandari, Roro Isyawati Permata Ganggi) 


\section{Kontribusi Pada Keilmuan}

Penelitian ini merupakan kajian dalam bidang Perpustakaan dan Kearsipan yang mengkaji tentang arsip digital. Hasil penelitian ini dapat menjadi dasar untuk penelitian selanjutnya atau penelitian bidang sejenis mengenai pengelolaan arsip digital. Penelitian ini juga dapat menjadi sumber inspirasi bagi penelitian bidang lain yang berhubungan dengan cloud storage sebagai media penyimpanan arsip digital.

\section{Pernyataan Minat Kajian}

Peneliti bernama Sinta wulandari memiliki minat kajian dalam bidang kearsipan, sedangkan peneliti bernama Roro Isyawati Permata Ganggi memiliki minat kajian dalam bidang Perpustakaan.

\section{Kontribusi Peneliti dan Pihak Lain}

Peneliti dengan nama Sinta Wulandari melakukan wawancara dan observasi untuk mendapatkan data lapangan dan melakukan pengolahan data. Peneliti dengan nama Roro Isyawati Permata Ganggi melakukan pengumpulan data dengan cara studi pustaka juga analisis data.

\section{DAFTAR PUSTAKA}

Alharbi, S., \& Drew, S. (2014). Using the technology acceptance model in understanding academics' behavioural intention to use learning management systems. International Journal of Advanced Computer Science and Applications, 5(1). 143-155. https://doi.org/10.14569/IJACSA.2014.050120

Burnett, G., \& Jaeger, P. T. (2011). Chapter 7 the theory of information worlds and information behaviour (1st ed.). Britania: Emerald Group Publishing Limited. https://doi.org/https://doi.org/10.1108/S1876-0562(2011)002011a010

Dwi, A. E. (2013). Pemanfaatan teknologi informasi: Studi deskriptif mengenai pemanfaatan teknologi informasi pada SMK Negeri 1 dan SMK Negeri 4 Surabaya (Skripsi) [Universitas Airlangga, Surabaya]. Retrieved from http://repository.unair.ac.id/id/eprint/15332

Heriyanto. (2018). Thematic analysis sebagai metode menganalisa data untuk penelitian kualitatif. Anuva, 2(3), 317-324. https://doi.org/10.14710/anuva.2.3.317-324

Iskandar. (2013). Metodologi penelitian pendidikan dan sosial (Kuantitatif dan kualitatif). Jakarta: Gaung Persada Press.

Lenawati, M. (2018). Penerapan cloud storage dalam perkuliahan Fakultas Teknik Universitas PGRI Madiun. RESEARCH: Computer, Information System \& Technology Management, 1(2), 55. https://doi.org/10.25273/research.v1i02.3372

Mildawati, T. (2016). Teknologi informasi dan perkembangannya di Indonesia. EKUITAS $\begin{array}{lllll}\text { (Jurnal Ekonomi Dan } & 101 .\end{array}$ https://doi.org/10.24034/j25485024.y2000.v4.i2.1904

Moleong, L. J. (2000). Metodologi penelitian kualitatif. Bandung: Remaja Rosdakarya. 
Muhidin, S. A., Winata, H., \& Santoso, B. (2016). Pengelolaan arsip digital. Jurnal Pendidikan Dan Manajemen, 2(3), 178-183. Retrieved from http://journal2.um.ac.id/index.php/jpbm/article/view/1708

Ni'matussholiha, A. (2016). Google drive for storing archives mengoptimasi penggunaan google drive sebagai tempat penyimpanan arsip bagi belajar. Khazanah Jurnal Pengembangan Kearsipan, $9(1), \quad 11-22 . \quad$ Retrieved from https://journal.ugm.ac.id/khazanah/article/view/22944/15214

Oh, K. E. (2019). Personal information organization in everyday life: Modeling the process. Journal of Documentation, 75(3), 667-691. https://doi.org/10.1108/JD-05-2018-0080

Read, J. dan Ginn, M.L.. (2011). Records management (9th Ed.). South-Western, USA: Cengage Learning.

Santiko, I., \& Rosidi, R. (2018). Pemanfaatan private cloud storage sebagai media penyimpanan data e-learning pada lembaga pendidikan. Jurnal Teknik Informatika, 10(2), 137-146. https://doi.org/10.15408/jti.v10i2.6992

Srinivasan, A., Quadir, M. A., \& Vijayakumar, V. (2015). Era of cloud computing: A new insight to hybrid cloud. Procedia Computer Science, 50, 42-51. https://doi.org/10.1016/j.procs.2015.04.059

Wahyuni, S. (2012). Qualitative research method: theory and practice. Jakarta: Salemba Empat.

Widjaja, A. E., Chen, J. V., Sukoco, B. M., \& Ha, Q. A. (2019). Understanding users' willingness to put their personal information on the personal cloud-based storage applications: An empirical study. Computers in Human Behavior, 91, 167-185. https://doi.org/10.1016/j.chb.2018.09.034 